\title{
Article \\ Chemical Composition of Lupin (Lupinus spp.) as Influenced by Variety and Tillage System
}

\author{
Katarzyna Panasiewicz (D)
}

check for

updates

Citation: Panasiewicz, K. Chemical Composition of Lupin (Lupinus spp.) as Influenced by Variety and Tillage System. Agriculture 2022, 12, 263. https: / / doi.org/10.3390/ agriculture 12020263

Received: 19 December 2021

Accepted: 9 February 2022

Published: 12 February 2022

Publisher's Note: MDPI stays neutral with regard to jurisdictional claims in published maps and institutional affiliations.

Copyright: (C) 2022 by the author. Licensee MDPI, Basel, Switzerland. This article is an open access article distributed under the terms and conditions of the Creative Commons Attribution (CC BY) license (https:// creativecommons.org/licenses/by/ $4.0 /)$
Department of Agronomy, Faculty of Agronomy, Horticulture and Bioengineering, Poznań University of Life Sciences, Dojazd 11 str., 60-632 Poznań, Poland; katarzyna.panasiewicz@up.poznan.pl

\begin{abstract}
Lupins are an important source of domestic protein in many countries, and are often considered as an alternative to soybeans, given their elevated and high-quality protein content, suitability for sustainable production and consumer acceptability. The aim of the research was to determine the effect of the variety (indeterminate and determinate) and tillage system (conventional$\mathrm{CT}$, reduced tillage $-\mathrm{RT}$, no-tillage $-\mathrm{NT}$ ) on the chemical composition of three lupin species seeds (narrow leaved lupin-NL, yellow lupin-YL, white lupin-WL). The protein content of the lupin seeds ranged from $323 \mathrm{~g} \mathrm{~kg}^{-1} \mathrm{DM}$ in the narrow-leaved lupin 'Dalbor' to $445 \mathrm{~g} \mathrm{~kg}^{-1} \mathrm{DM}$ in the yellow lupin 'Lord'. The tillage system significantly influenced the crude protein content only in NL seeds, with the greatest value observed with the NT system. An evaluation of the amino acid composition of the protein in the lupin seeds showed that the differences depended largely on the variation between the species. The conducted research shows that the varietal differentiation in terms of the amino acid content was particularly evident in NL and YL, and, to a lesser extent, in WL.
\end{abstract}

Keywords: indeterminate; determinate; reduced tillage; no-tillage; macro elements; amino acid; lupin

\section{Introduction}

The systematic growth of the world's population has caused a simultaneous increase in the demand for food. The basis for food production in many countries are seeds, which, in addition to direct consumption, are a processed food for animal feed production. Livestock production in the European Union (EU) is highly dependent on imported soybeans, which exposes the livestock farming system to risks related to the global trade of that crop [1]. Legume seeds are the second most important global plant protein source after cereals [2], and legumes or pulses are an important element of sustainable agricultural production, human nutrition and livestock feed [1,3]. Lupin (Lupinus spp.) can be a good alternative to genetically modified organism (GMO) soybeans, as it is a valuable source of protein for human consumption and can be used as a livestock feed in the form of seeds, forage and silage [4]. Processing methods include soaking after roasting, boiling, germination, fermentation and alkaline treatments [5]. Furthermore, legumes can be grown on less fertile, acidic and sandy soils where other crops produce lower yields, and are preferred in crop rotations, as they have a positive impact on the yield of subsequent crops [6-8]. Lupin species have been shown to have a relatively high tolerance to various environmental stresses, nitrate excess, low root temperature, lime excess and salinity, and could therefore be cultivated worldwide [9]. Furthermore, this plant is very important in plant production as it can fix nitrogen $\left(\mathrm{N}_{2}\right)$ from the atmosphere, thereby increasing the concentration in the soil of one the most important plant nutrients [10].

The use of plant-based protein isolates in food formulations has recently become of interest due to greater sustainability and lower production costs [11]. According to Lucas et al., [4] sustainable, innovative and cost-efficient processing methods to produce high-protein ingredients should be devised to guarantee the socio-economic value of the crops. 
The feed and nutritional value of legumes seeds is determined by their chemical composition, which include the protein content and amino acid composition [3]. As a result of plant breeding research, it is now possible to obtain lupin varieties with a predetermined growth, characterized by a shorter growing period and an associated earlier and more uniform maturation, as well as the dynamics of assimilation accumulation in the biological and agricultural yield, which is different from traditional varieties. Moreover, these varieties are characterized by an absence or strong reduction in side shoots (depending on the plant density), which changes the light conditions in the canopy due to mutual shading of plants [12].

Seed quality, e.g., the protein and alkaloid content, are determine by the gene pool (species, variety) but also by environmental [13] and agrotechnical factors [14,15]. The chemical composition of legume seeds, such as pea [15], yellow lupin [16] and soybean [17] can be modified by the tillage system. Woźniak and Rachon [16] observed that the potassium content in yellow lupin seeds decreased in a no-tillage (NT) system compared to conventional (CT) and reduced tillage (RT) systems. The selection of varieties may be a basic condition for successful lupin production $[1,18]$. However, there is a paucity of published studies on the effect of the variety and tillage system on the chemical properties of lupin seeds. An overview of literature data [19-22] indicates that individual chemical constituents are distributed over a relatively wide range depending on species. Of particular importance is the response of lupin varieties to practical simplifications in the tillage system, which are increasingly introduced for economic reasons. These simplifications can influence the seed quality. The reported variability in lupin varieties would indicate a need to determine the appropriate cultivation technology for each variety, which will also take into account the soil tillage system.

The aim of our study was to confirm or contradict this opinion, as well as to assess the impact of various tillage systems on the chemical components of three lupin species of determinate and indeterminate varieties.

\section{Materials and Methods}

\subsection{Experimental Design and Agronomic Management}

The field study was conducted at the Przebedowo Research Station, Wielkopolska, Poland $\left(52^{\circ} 35^{\prime} \mathrm{N}, 17^{\circ} 10^{\prime} \mathrm{E}\right)$ in $2014-2015$. The experiment was located on fields formed from light loamy sands, quality classes IVa and IVb, very good and good rye complex, classified according to the IUSS Working Group WRB [23] as Albic Luvisols on a gray-brown podsolic $\left(\mathrm{pH}=6.5\right.$ measured in $1 \mathrm{M} \mathrm{KCl} ; 0.8 \%$ organic matter: organic carbon-75.6 mg $100 \mathrm{~g} \mathrm{soil}^{-1}$; 50-110 mg P kg-1; 115-195 mg K kg-1). For each species, the experiments were assumed to be two-factorial, in a system of random complete blocks, in four repetitions. The forecrop during the years of the study was winter rye. The research factors for each species were: variety (indeterminate: narrow leaved lupin (NL) —'Dalbor', yellow lupin (YL)_'Lord', white lupin (WL) - 'Butan'; determinate: NL—'Regent', YL-'Perkoz', WL-'Boros'); and tillage system (conventional-CT, reduced tillage- $-\mathrm{RT}$, no-tillage-NT). The conventional system included the full range of cultivation after pre-harvesting: discing, pre-winter ploughing and pre-sowing. The RT system was simplified by the replacement of ploughing with a disc harrow. In NT, no soil tillage was abandoned, and one application of herbicide Roundup 360 SL (glyphosate) at a rate of $2.0 \mathrm{~L} \mathrm{ha}^{-1}$ was applied in the autumn. Prior to sowing, the seeds were dressed with Vitavax $200 \mathrm{FS}$ (200 $\mathrm{g} \mathrm{dm}^{3}$, carboxin and tiuram) and were inoculated with Bradyrhizobium sp. (Nitragina). The number of germinated seeds was 120 pcs for the indeterminate varieties, sown at a rate of $170 \mathrm{~kg} \mathrm{ha}^{-1}$, and $100 \mathrm{pcs}$ for determinate varieties, sown at a rate of $140 \mathrm{~kg} \cdot \mathrm{ha}^{-1}$. Sowing was performed with a direct sowing machine (Tüme-Agri oy, Turenki, Finland) and the seeds were sown in the third week of March. Row spacing was $15 \mathrm{~cm}$ and sowing depth was 3-4 cm. Before sowing, phosphorus fertilization at $100 \mathrm{~kg} \mathrm{P}_{2} \mathrm{O}_{5} \mathrm{ha}^{-1}\left(43.6 \mathrm{~kg} \mathrm{P} \mathrm{ha}^{-1}\right)$ and potassium fertilization $100 \mathrm{~kg} \mathrm{~K}{ }_{2} \mathrm{O}\left(83 \mathrm{~kg} \mathrm{~K} \mathrm{ha}^{-1}\right)$ were applied. Immediately after sowing, weed control was carried out with linuron (Afalon Dyspersyjny $450 \mathrm{SC}$ ) at a rate of $1.25 \mathrm{~L} \mathrm{ha}^{-1}$. In addition, 
monocotyledonous weeds were treated with quizalofop-p-ethyl (Leopard Extra 05 EC) at a rate of $2.0 \mathrm{dm}^{3} \mathrm{ha}^{-1}$. Protection of the canopy against fungal pathogens was performed prophylactically with tetrachloroizoftalonitryl (Gwarant $500 \mathrm{SC}$ ) at a rate of $2.0 \mathrm{~L} \mathrm{ha}^{-1}$ at the budding phase of the plants. Seed harvesting (at a 15\% moisture content) was carried out once, annually in August, using a $1.5 \mathrm{~m}$ wide Wintersteiger Classic Plot Combine. The area of each plot was $48 \mathrm{~m}^{2}$. The remaining agrotechnical treatments were performed in accordance with good agricultural practice for this species.

\subsection{Weather Conditions}

It is generally accepted that climatic conditions found throughout Poland are suitable for lupin cultivation. Weather conditions during the vegetation period in the years of study are presented using the hydrothermal index according to Walter [24] (Figure 1). In both years of the study, drought was not recorded, which indicates that, at the most critical development period of lupin, i.e., during florescence (June) and the emergence of pods (July), the plants received a relatively good supply of water.

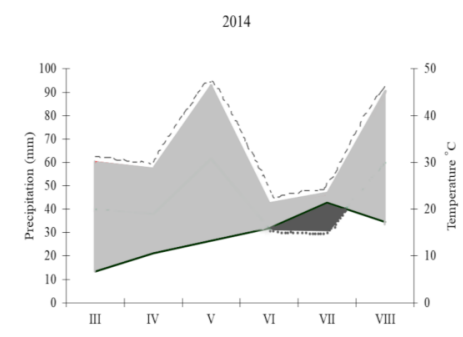

(a)

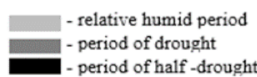

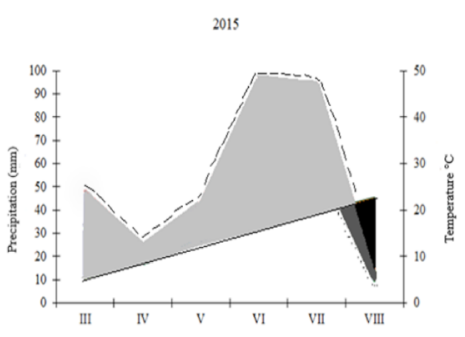

(b)

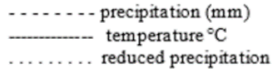

Figure 1. Climatic data characterizing weather conditions in Przebedowo, Poland in the experimental area during growing seasons (a) 2014 and (b) 2015 prepared according to Walter (1976).

\subsection{Chemical Composition Analysis}

A random sample of seeds was taken from each plot after harvesting for chemical analysis. The samples were stored in closed containers at $4{ }^{\circ} \mathrm{C}$. The samples were ground to pass through a $0.5 \mathrm{~mm}$ sieve using a laboratory grinder $\mathrm{W} \dot{Z}-1$. Analysis of the basic chemical composition included determination of dry matter (DM), content crude protein (CP) and crude fiber (CF) content, which were determined according to standard AOAC procedures [25]. The nitrogen content of the seeds was determined with the Kjeldahl method and expressed as total protein content $(\mathrm{N} \times 6.25)$, crude fat $(\mathrm{CF})$ content was determined with the Soxhlet method, CF was determined by hydrolyzation of the other components of the plant material and crude ash (CA) was determined by incineration. Nitrogen-free extracts (NFE) were calculated as NFE $=\mathrm{DM}-(\mathrm{CP}+\mathrm{CA}+\mathrm{CF})$.

$\mathrm{DM}$-dry matter, $\mathrm{CP}$ - crude protein, $\mathrm{CA}$ - crude ash, $\mathrm{CF}$ - crude fiber.

Seed samples for analyses of macroelement content $(\mathrm{N}, \mathrm{P}, \mathrm{K}, \mathrm{Mg}, \mathrm{Ca})$ were collected at harvest time with a combine harvester. Macroelement content was determined at the Chemical Laboratory in Poznan University of Life Science, using the following methods: nitrogen by potentiometry, phosphorus with the vanadate-molybdate method in a Specol 11 spectrocolometer, spectrometric method in line with the standard PN-ISO 6491 (2000) and magnesium in a Flavo 4 apparatus.

The amino acid (AA) content was determined by an AAA-400 Automatic Amino Acid Analyzer (INGOS s.r.o., Praha, Czech Republic), using ninhydrin for post-column derivatization. Before analysis the samples were hydrolyzed with $6 \mathrm{NHCl}$ for $24 \mathrm{~h}$ at $110^{\circ} \mathrm{C}$ (procedure 994.12); AOAC [17]. Tryptophan was not measured. The quality of protein was estimated by determination of total AA, as well as the fractions of the exogenous amino 
acids ( $\left.\sum E A A\right)$ and non-essential amino acids ( $\sum$ NEAA). Amino acid determinations were expressed on a $\mathrm{g} 16 \mathrm{~g} \mathrm{~N}^{-1}$ basis.

\subsection{Statistical Analysis}

All analyses were carried out in four replications. Data were processed using two-way analysis of variance (ANOVA) with the SAS package [26]. Treatment means were compared using Tukey's multiple range test and the least significant difference (LSD) was declared at the $p<0.05$ and $p<0.01$ levels. The data presented in the study accounted for the mean values from two years due to the lack of significant differences between the years that the parameters were assessed.

An experimental variant heatmap with cluster analyses was created to analyze the similarities between AA, seed yield and protein yield depending on variety and tillage system. Data transformation using 'normalize' was used to compare and group different data. Euclidean distance measures and Ward hierarchical clustering were used to determine the dendrogram.

\section{Results}

\subsection{Organic Components, Ash and Macroelements}

In the narrow-leaved lupin seeds, the organic components and ash content were not affected by the variety, or by the interaction between the variety and tillage system, in contrast to the seeds of the yellow lupin and white lupin varieties (Table 1). In yellow lupin seeds, the variety resulted in differences in the CF and CL contents $(p<0.01)$, but only for CL in the case of white lupin $(p<0.05)$. A significant effect of the tillage system was observed on the protein content $(p<0.01)$ in narrow-leaved lupin seeds and on the fiber content $(p<0.05)$ in yellow lupin seeds. During the study period, the combined effect of these factors on the content of organic compounds and ash was not demonstrated. The twoway ANOVA showed no significant effect of the tillage system and the interaction between the variety and tillage system on the content of macroelements in the narrow-leaved lupin and yellow lupin seeds.

Table 1. Factorial ANOVA with variety, tillage system and interaction for the content of organic components, ash and macroelements in lupin.

\begin{tabular}{|c|c|c|c|c|c|c|c|c|c|c|c|c|}
\hline Specification & df & $\mathrm{CP}$ & CF & A & CL & NFE & $\mathbf{N}$ & $\mathbf{P}$ & Mg & $\mathrm{Na}$ & $\mathbf{K}$ & $\mathrm{Ca}$ \\
\hline \multicolumn{13}{|c|}{$\mathrm{NL}^{1}$} \\
\hline Variety (A) & 1 & $\mathrm{~ns}^{2}$ & ns & ns & ns & ns & ns & ns & ns & ns & $*$ & ns \\
\hline Tillage system (B) & 2 & $* *$ & ns & ns & ns & ns & ns & ns & ns & ns & ns & ns \\
\hline $\mathrm{A} \times \mathrm{B}$ & 2 & ns & ns & ns & ns & ns & ns & ns & ns & ns & ns & ns \\
\hline \multicolumn{13}{|c|}{ YL } \\
\hline Variety (A) & 1 & ns & $* *$ & ns & $* *$ & ns & ns & ns & * & ns & ns & ns \\
\hline Tillage system (B) & 2 & ns & $*$ & ns & ns & ns & ns & ns & ns & ns & ns & ns \\
\hline $\mathrm{A} \times \mathrm{B}$ & 2 & ns & ns & ns & ns & ns & ns & ns & ns & ns & ns & ns \\
\hline \multicolumn{13}{|c|}{ WL } \\
\hline Variety (A) & 1 & $\mathrm{~ns}$ & $\mathrm{~ns}$ & ns & * & $\mathrm{ns}$ & ns & $* *$ & $\mathrm{~ns}$ & ns & $\mathrm{ns}$ & ns \\
\hline Tillage system (B) & 2 & * & ns & ns & ns & ns & ns & $* *$ & ns & ns & ns & ns \\
\hline $\mathrm{A} \times \mathrm{B}$ & 2 & ns & ns & ns & ns & ns & ns & $*$ & ns & ns & ns & ns \\
\hline
\end{tabular}

The statistical evaluation also showed a significant differentiation of varieties in terms of the content of selected macroelements in seeds for individual species, potassium in the narrow-leaved lupin seeds and magnesium in the yellow lupin seeds $(p<0.05)$. In the 
white lupin seeds, differences in the phosphorus content for both experimental factors $(p<0.01)$ and their interaction $(p<0.05)$ were observed.

The results of our study indicate that the content was related to the species and variety (Table 2).

Table 2. Content ( $\left.\mathrm{g} \mathrm{kg}^{-1} \mathrm{DM}\right)$ of organic components and ash in lupin seeds depending on the variety and tillage system.

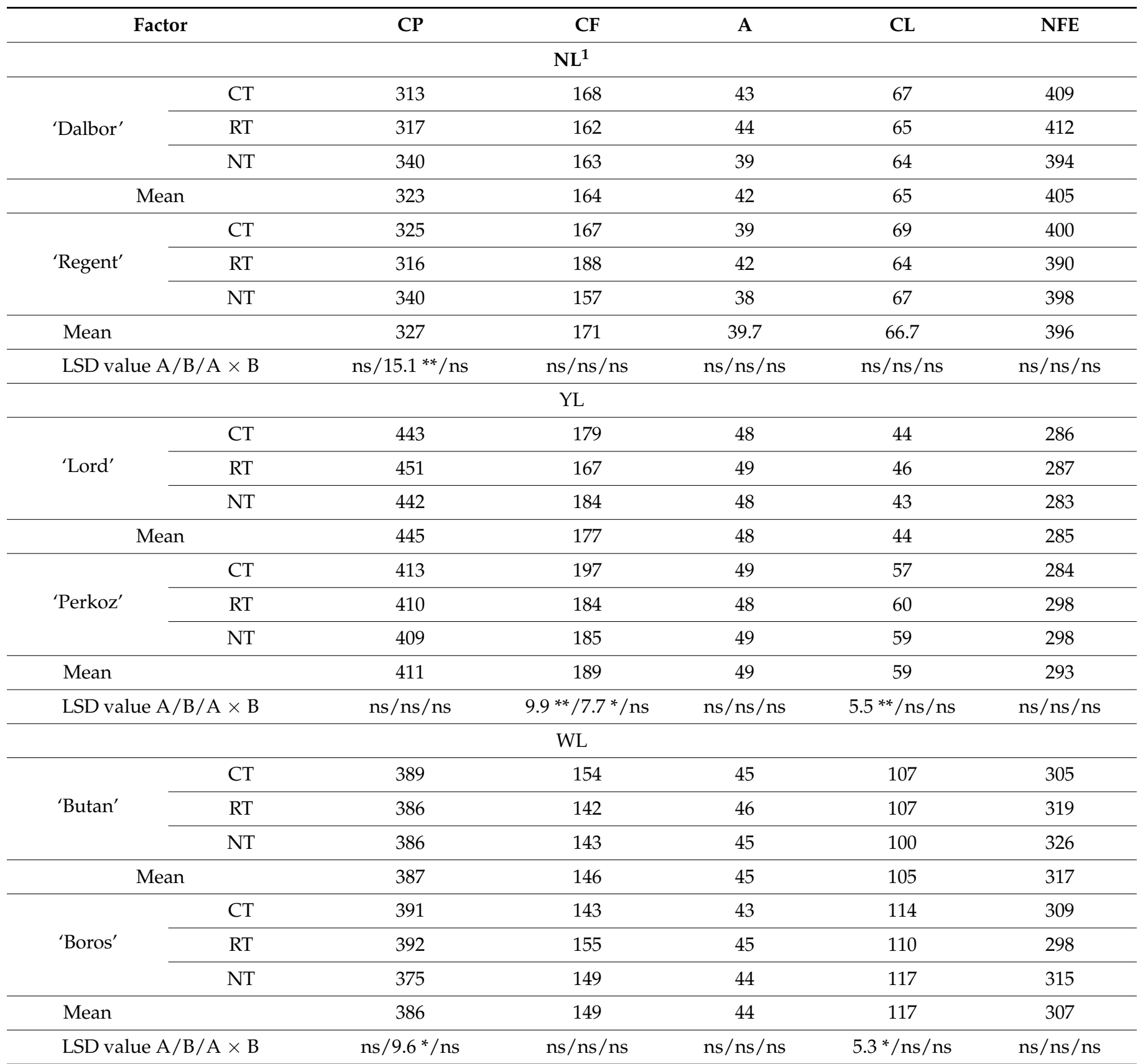

$\mathrm{NL}^{1}$ —narrow-leaved lupin; YL-yellow lupin; $\mathrm{WL}$-white lupin; $\mathrm{CP}$-crude protein, $\mathrm{CF}$-crude fiber, A—ash, CL—crude lipides, NFE-nitrogen-free extract; CT—conventional tillage; RT—reduced tillage; NT—no-tillage; ns-not significant; ${ }^{*} p<0.05$ and ${ }^{* *} p<0.01$

The highest protein content was recorded in the yellow lupin seeds: $445 \mathrm{~g} \mathrm{~kg}^{-1} \mathrm{DM}$ in the indeterminate 'Lord' and $411 \mathrm{~g} \mathrm{~kg}^{-1} \mathrm{DM}$ in the determinate 'Perkoz'. The lowest CP content was observed in narrow-leaved lupin seeds, indeterminate 'Dalbor' ( $323 \mathrm{~g} \mathrm{~kg}^{-1}$ $\mathrm{DM}$ ) and determinate 'Regent' ( $\left.327 \mathrm{~g} \mathrm{~kg}^{-1} \mathrm{DM}\right)$. In our study, the tillage system significantly modified the $\mathrm{CP}$ content in narrow-leaved lupin seeds. The highest protein content was 
found in seeds from NT (340 $\left.\mathrm{g} \mathrm{kg}^{-1} \mathrm{DM}\right)$. In the yellow lupin seeds, the tillage system had a significant effect on the CF content. In comparison to the CT system, RT reduced the content of this component by $13 \mathrm{~g} \mathrm{~kg}^{-1} \mathrm{DM}$, i.e., $6.9 \%$. In all three lupin species, the analyzed varieties and tillage systems did not differ significantly in terms of the A and NFE content. In the yellow lupin seeds, the determinate 'Perkoz' exhibited the greatest CF ( $\left.189 \mathrm{~g} \mathrm{~kg}^{-1} \mathrm{DM}\right)$ and CL contents $\left(959 \mathrm{~g} \mathrm{~kg}^{-1} \mathrm{DM}\right)$. In the white lupin seeds, a greater CL content was noted in the determinate 'Boros' (114 $\left.\mathrm{g} \mathrm{kg}^{-1} \mathrm{DM}\right)$. Across all examined lupins in our experiment, the greatest $\mathrm{N}, \mathrm{P}$ and $\mathrm{Mg}$ contents were observed in the yellow lupin seeds (Table 3).

Table 3. Macroelements ( $\mathrm{mg} \mathrm{g}^{-1}$ dry mass) in lupin seeds.

\begin{tabular}{|c|c|c|c|c|c|c|c|}
\hline \multicolumn{2}{|c|}{ Factor } & $\mathbf{N}$ & $\mathbf{P}$ & $\mathrm{Mg}$ & $\mathbf{N a}$ & $\mathbf{K}$ & $\mathrm{Ca}$ \\
\hline \multicolumn{8}{|c|}{ NL } \\
\hline \multirow{3}{*}{ 'Dalbor' } & $\mathrm{CT}$ & 48.4 & 4.4 & 1.69 & 0.13 & 6.47 & 1.51 \\
\hline & $\mathrm{RT}$ & 48.5 & 4.2 & 1.65 & 0.10 & 6.26 & 1.50 \\
\hline & NT & 51.5 & 4.2 & 1.80 & 0.13 & 6.05 & 1.41 \\
\hline \multicolumn{2}{|c|}{ Mean } & 49.5 & 4.3 & 1.71 & 0.12 & 6.26 & 1.47 \\
\hline \multirow{3}{*}{ ‘Regent’ } & $\mathrm{CT}$ & 48.2 & 4.1 & 1.86 & 0.10 & 10.66 & 1.36 \\
\hline & $\mathrm{RT}$ & 48.0 & 4.6 & 1.82 & 0.10 & 11.11 & 1.56 \\
\hline & NT & 51.7 & 4.0 & 1.69 & 0.11 & 10.02 & 1.41 \\
\hline \multicolumn{2}{|l|}{ Mean } & 49.3 & 4.2 & 1.79 & 0.10 & 10.60 & 1.44 \\
\hline \multicolumn{2}{|c|}{ LSD value $\mathrm{A} / \mathrm{B} / \mathrm{A} \times \mathrm{B}$} & $\mathrm{ns} / \mathrm{ns} / \mathrm{ns}$ & $\mathrm{ns} / \mathrm{ns} / \mathrm{ns}$ & $\mathrm{ns} / \mathrm{ns} / \mathrm{ns}$ & $\mathrm{ns} / \mathrm{ns} / \mathrm{ns}$ & $4.09 * / \mathrm{ns} / \mathrm{ns}$ & $\mathrm{ns} / \mathrm{ns} / \mathrm{ns}$ \\
\hline \multicolumn{8}{|c|}{ YL } \\
\hline \multirow{3}{*}{ 'Lord' } & $\mathrm{CT}$ & 62.3 & 6.2 & 3.1 & 0.10 & 11.69 & 1.16 \\
\hline & RT & 64.9 & 6.6 & 3.1 & 0.20 & 11.87 & 1.26 \\
\hline & NT & 63.2 & 6.2 & 2.9 & 0.10 & 11.73 & 1.20 \\
\hline \multirow[t]{2}{*}{ Mean } & & 63.5 & 6.3 & 3.0 & 0.13 & 11.76 & 1.21 \\
\hline & $\mathrm{CT}$ & 59.7 & 6.1 & 2.5 & 0.10 & 11.85 & 1.46 \\
\hline \multirow[t]{2}{*}{ ‘Perkoz' } & RT & 60.3 & 6.0 & 2.8 & 0.10 & 12.15 & 1.36 \\
\hline & $\mathrm{NT}$ & 57.9 & 6.4 & 2.5 & 0.10 & 11.70 & 1.66 \\
\hline \multicolumn{2}{|l|}{ Mean } & 59.3 & 6.2 & 2.6 & 0.10 & 11.90 & 1.49 \\
\hline \multicolumn{2}{|c|}{ LSD value $\mathrm{A} / \mathrm{B} / \mathrm{A} \times \mathrm{B}$} & $\mathrm{ns} / \mathrm{ns} / \mathrm{ns}$ & $\mathrm{ns} / \mathrm{ns} / \mathrm{ns}$ & $0.39 * / \mathrm{ns} / \mathrm{ns}$ & $\mathrm{ns} / \mathrm{ns} / \mathrm{ns}$ & $\mathrm{ns} / \mathrm{ns} / \mathrm{ns}$ & $\mathrm{ns} / \mathrm{ns} / \mathrm{ns}$ \\
\hline \multicolumn{8}{|c|}{ WL } \\
\hline \multirow{3}{*}{ 'Butan' } & $\mathrm{CT}$ & 56.8 & 4.8 & 1.8 & 0.10 & 12.10 & 0.15 \\
\hline & RT & 58.0 & 5.0 & 1.8 & 0.10 & 12.00 & 0.15 \\
\hline & NT & 56.7 & 4.8 & 1.8 & 0.10 & 12.00 & 0.15 \\
\hline Mean & & 57.2 & 4.9 & 1.8 & 0.10 & 12.03 & 0.15 \\
\hline \multirow{3}{*}{ 'Boros' } & $\mathrm{CT}$ & 55.4 & 4.3 & 1.8 & 0.10 & 11.80 & 0.15 \\
\hline & $\mathrm{RT}$ & 56.3 & 4.9 & 1.8 & 0.10 & 11.90 & 0.15 \\
\hline & NT & 55.8 & 4.7 & 1.9 & 0.10 & 12.10 & 0.15 \\
\hline \multicolumn{2}{|l|}{ Mean } & 55.8 & 4.6 & 1.8 & 0.10 & 11.93 & 0.15 \\
\hline \multicolumn{2}{|c|}{ LSD value $A / B / A \times B$} & $\mathrm{~ns} / \mathrm{ns} / \mathrm{ns}$ & $\begin{array}{c}0.16^{* *} / 0.19 \\
* * / 0.17^{*}\end{array}$ & $\mathrm{~ns} / \mathrm{ns} / \mathrm{ns}$ & $\mathrm{ns} / \mathrm{ns} / \mathrm{ns}$ & $\mathrm{ns} / \mathrm{ns} / \mathrm{ns}$ & $\mathrm{ns} / \mathrm{ns} / \mathrm{ns}$ \\
\hline
\end{tabular}


Our analysis of mean showed that the variety modified the potassium content in the narrow-leaved lupin seeds, with the greatest content found in the seeds of the determinate 'Regent' (mean value: $-10.6 \mathrm{mg} \mathrm{g}^{-1} \mathrm{DM}$ ). Furthermore, the variety modified the magnesium content in the yellow lupin seeds, where the greatest content was found in the seeds of the indeterminate 'Lord' $-3.0 \mathrm{mg} \mathrm{Mg} \mathrm{g}^{-1} \mathrm{DM}$. The phosphorus content in the white lupin seeds was also dependent on the variety, tillage system and their interaction, with the greatest content observed in the indeterminate 'Butan' $\left(4.9 \mathrm{mg} \mathrm{P} \mathrm{g}^{-1} \mathrm{DM}\right)$ within each tillage system. Moreover, for both determinate and indeterminate varieties, the greatest phosphorus content was recorded in the RT seeds.

\subsection{Amino Acids}

The results of our study indicated that significantly greater levels of arginine were noted in the determinate 'Boros' white lupin (Table 4).

Table 4. Amino acid profile $\left(\mathrm{g} 16 \mathrm{~g}^{-1} \mathrm{~N}\right)$ of white lupin $(\mathrm{WL})$ depending on variety and tillage system.

\begin{tabular}{|c|c|c|c|c|c|c|c|c|c|c|c|c|c|c|c|c|c|c|c|c|}
\hline \multicolumn{2}{|c|}{ Factor } & Lys & Cys & Thr & Val & Met & Tyr & Leu & Phe & Ser & Pro & Gly & Ala & Iso & His & Arg & Asp & Glu & $\sum_{\text {NEAA }}$ & $\sum_{\text {EAA }}^{\sum}$ \\
\hline \multirow{3}{*}{ 'Butan' } & $\mathrm{CT}$ & 4.61 & 1.00 & 3.21 & 3.56 & 0.55 & 3.85 & 6.41 & 3.46 & 4.42 & 3.06 & 3.41 & 2.84 & 3.72 & 2.23 & 10.3 & 9.10 & 16.5 & 49.6 & 32.6 \\
\hline & RT & 5.18 & 1.02 & 3.69 & 0.98 & 0.58 & 4.29 & 7.15 & 3.91 & 4.87 & 3.34 & 3.81 & 3.19 & 4.18 & 2.46 & 11.3 & 10.2 & 18.3 & 55.0 & 33.4 \\
\hline & NT & 5.23 & 1.15 & 3.76 & 4.05 & 0.59 & 4.23 & 7.24 & 3.90 & 4.79 & 3.37 & 3.90 & 3.28 & 4.19 & 2.58 & 11.3 & 10.4 & 18.5 & 55.5 & 36.9 \\
\hline \multicolumn{2}{|c|}{ Mean } & 5.01 & 1.06 & 3.55 & 2.86 & 0.57 & 4.12 & 6.93 & 3.76 & 4.69 & 3.26 & 3.71 & 3.10 & 4.03 & 2.42 & 11.0 & 9.90 & 17.8 & 53.4 & 34.3 \\
\hline \multirow{3}{*}{ 'Boros' } & $\mathrm{CT}$ & 5.26 & 0.99 & 3.68 & 4.03 & 0.57 & 4.33 & 7.12 & 3.93 & 4.89 & 3.40 & 3.88 & 3.25 & 4.20 & 2.48 & 12.4 & 10.2 & 18.2 & 56.2 & 36.6 \\
\hline & RT & 5.25 & 1.01 & 3.70 & 4.03 & 0.60 & 4.35 & 7.09 & 3.93 & 4.84 & 3.42 & 3.84 & 3.22 & 4.22 & 2.42 & 12.3 & 10.3 & 18.1 & 56.0 & 36.6 \\
\hline & NT & 5.32 & 1.02 & 3.77 & 4.10 & 0.61 & 4.42 & 7.23 & 4.01 & 4.93 & 3.46 & 3.90 & 3.32 & 4.30 & 2.40 & 12.0 & 10.4 & 18.3 & 56.3 & 37.2 \\
\hline \multicolumn{2}{|l|}{ Mean } & 5.27 & 1.01 & 3.72 & 4.05 & 0.59 & 4.37 & 7.15 & 3.96 & 4.89 & 3.43 & 3.87 & 3.26 & 4.24 & 2.43 & 12.2 & 10.3 & 18.2 & 56.2 & 36.8 \\
\hline \multicolumn{21}{|c|}{ LSD value } \\
\hline \multirow{3}{*}{\multicolumn{2}{|c|}{$\begin{array}{l}\mathrm{A} \\
\mathrm{B} \\
\mathrm{A} \times \mathrm{B}\end{array}$}} & ns & ns & ns & ns & ns & ns & ns & ns & ns & ns & ns & $\mathrm{ns}$ & ns & ns & 1.14 * & ns & ns & 1.03 * & 1.11 * \\
\hline & & ns & ns & ns & ns & ns & ns & ns & ns & ns & ns & ns & ns & ns & ns & ns & ns & ns & 0.84 * & 0.95 * \\
\hline & & ns & ns & ns & ns & ns & ns & ns & ns & ns & ns & ns & ns & ns & ns & ns & ns & ns & 0.64 * & 0.48 * \\
\hline
\end{tabular}

CT-conventional tillage; RT—reduced tillage; NT—no-tillage; ns—not significant; $\sum$ NEAA—non-essential amino acids; $\sum$ EAA—exogenous amino acids; ${ }^{*} p<0.05$.

In the narrow-leaved lupin seeds, greater contents of leucine, phenylalanine, serine, isoleucine, aspartic acid and glutamic acid were found in the indeterminate 'Dalbor' (Table 5), whereas, in the yellow lupin seeds, lysine, threonine, valine, leucine, phenylalanine, glycine, alanine, isoleucine, aspartic acid and glutamic acid were greatest in the determinate 'Perkoz' (Table 6). The tillage system only caused insignificant differences in the phenylalanine and isoleucine contents in the narrow-leaved lupin seeds. For both these amino acids, the greatest content was observed in the indeterminate 'Dalbor'. 
Table 5. Amino acid profile ( $\left(16 \mathrm{~g}^{-1} \mathrm{~N}\right)$ of narrow-leaved lupin (NL) depending on variety and tillage system.

\begin{tabular}{|c|c|c|c|c|c|c|c|c|c|c|c|c|c|c|c|c|c|c|c|c|}
\hline \multicolumn{2}{|c|}{ Factor } & Lys & Cys & Thr & Val & Met & Tyr & Leu & Phe & Ser & Pro & Gly & Ala & Iso & His & Arg & Asp & Glu & $\sum$ NEAA & $\sum$ EAA \\
\hline \multirow{3}{*}{ 'Lord' } & $\mathrm{CT}$ & 5.33 & 1.48 & 3.10 & 3.44 & 0.54 & 2.70 & 7.10 & 3.78 & 4.63 & 3.03 & 3.63 & 3.06 & 3.65 & 2.81 & 12.5 & 9.34 & 19.8 & 56.0 & 33.9 \\
\hline & RT & 5.45 & 1.48 & 3.16 & 3.52 & 0.55 & 2.82 & 7.22 & 3.90 & 4.70 & 3.07 & 3.72 & 3.13 & 3.76 & 2.89 & 13.0 & 9.59 & 20.1 & 57.3 & 34.7 \\
\hline & NT & 5.52 & 1.44 & 3.24 & 3.59 & 0.56 & 2.87 & 7.31 & 3.94 & 4.74 & 3.17 & 3.78 & 3.18 & 3.84 & 2.91 & 13.1 & 9.70 & 20.2 & 57.9 & 35.2 \\
\hline \multirow{3}{*}{ ‘Perkoz' } & $\mathrm{CT}$ & 5.74 & 1.60 & 3.42 & 3.68 & 0.56 & 2.92 & 7.59 & 4.05 & 4.69 & 3.12 & 3.88 & 3.29 & 3.92 & 2.95 & 12.4 & 9.88 & 20.9 & 58.2 & 36.4 \\
\hline & RT & 5.84 & 1.53 & 3.48 & 3.77 & 0.56 & 2.97 & 7.75 & 4.15 & 4.92 & 3.20 & 3.97 & 3.33 & 4.00 & 3.01 & 12.4 & 10.1 & 21.1 & 59.0 & 37.1 \\
\hline & NT & 5.69 & 1.54 & 3.35 & 3.67 & 0.56 & 2.89 & 7.54 & 4.05 & 5.00 & 3.12 & 3.90 & 3.30 & 3.90 & 2.95 & 12.2 & 9.88 & 20.9 & 58.3 & 36.1 \\
\hline \multicolumn{2}{|l|}{ Mean } & 5.76 & 1.56 & 3.42 & 3.71 & 0.56 & 2.93 & 7.63 & 4.08 & 4.87 & 3.15 & 3.91 & 3.31 & 3.94 & 2.97 & 12.3 & 9.95 & 20.9 & 58.5 & 36.5 \\
\hline \multicolumn{21}{|c|}{ LSD value } \\
\hline \multicolumn{2}{|c|}{$\begin{array}{l}\text { A } \\
\text { B }\end{array}$} & $0.23 *$ & ns & $0.20^{* *}$ & $0.18^{*}$ & ns & ns & $0.40^{* *}$ & $0.13^{*}$ & ns & ns & $0.16^{*}$ & $0.14^{*}$ & 0.18 * & ns & $0.50^{*}$ & $0.37^{*}$ & $0.65^{*}$ & $0.31^{* *}$ & $1.21 * *$ \\
\hline \multicolumn{2}{|c|}{$A \times B$} & $\begin{array}{l}\text { ns } \\
\text { ns }\end{array}$ & $\begin{array}{l}\text { ns } \\
\text { ns }\end{array}$ & $\begin{array}{l}\text { ns } \\
\text { ns }\end{array}$ & $\begin{array}{l}\text { ns } \\
\text { ns }\end{array}$ & $\begin{array}{l}\text { ns } \\
\text { ns }\end{array}$ & $\begin{array}{l}\text { ns } \\
\text { ns }\end{array}$ & $\begin{array}{l}\text { ns } \\
\text { ns }\end{array}$ & $\begin{array}{l}\text { ns } \\
\text { ns }\end{array}$ & $\begin{array}{l}\text { ns } \\
\text { ns }\end{array}$ & $\begin{array}{l}\mathrm{ns} \\
\mathrm{ns}\end{array}$ & $\begin{array}{l}\text { ns } \\
\text { ns }\end{array}$ & $\begin{array}{l}\text { ns } \\
\text { ns }\end{array}$ & $\begin{array}{l}\text { ns } \\
\text { ns }\end{array}$ & $\begin{array}{l}\text { ns } \\
\text { ns }\end{array}$ & $\begin{array}{l}\text { ns } \\
\text { ns }\end{array}$ & $\begin{array}{l}\text { ns } \\
\text { ns }\end{array}$ & $\begin{array}{l}\text { ns } \\
\text { ns }\end{array}$ & $\begin{array}{l}0.20^{*} \\
0.16^{*}\end{array}$ & $\begin{array}{l}0.92^{*} \\
0.75^{*}\end{array}$ \\
\hline
\end{tabular}

CT—conventional tillage; RT—reduced tillage; NT—no-tillage; ns—not significant; $\sum$ NEAA—non-essential amino acids; $\sum$ EAA—exogenous amino acids; ${ }^{*} p<0.05$ and ${ }^{* *} p<0.01$.

Table 6. Amino acid profile ( $16 \mathrm{~g}^{-1} \mathrm{~N}$ ) of yellow lupin (YL) depending on variety and tillage system.

\begin{tabular}{|c|c|c|c|c|c|c|c|c|c|c|c|c|c|c|c|c|c|c|c|c|}
\hline \multicolumn{2}{|c|}{ Factor } & Lys & Cys & Thr & Val & Met & Tyr & Leu & Phe & Ser & Pro & Gly & Ala & Iso & His & Arg & Asp & Glu & $\sum_{\text {NEAA }}$ & $\sum$ EAA \\
\hline \multirow{3}{*}{ ‘Dalbor' } & CT & 5.52 & 0.95 & 3.76 & 4.27 & 0.54 & 3.72 & 7.32 & 4.26 & 5.05 & 3.59 & 4.40 & 3.59 & 4.39 & 3.11 & 12.2 & 10.6 & 20.1 & 59.5 & 37.8 \\
\hline & RT & 5.51 & 0.94 & 3.65 & 4.17 & 0.55 & 3.58 & 7.16 & 4.21 & 5.02 & 3.55 & 4.30 & 3.53 & 4.30 & 3.06 & 12.1 & 10.1 & 20.0 & 58.6 & 37.1 \\
\hline & NT & 5.43 & 0.91 & 3.55 & 4.03 & 0.50 & 3.53 & 6.94 & 4.02 & 4.91 & 3.47 & 4.13 & 3.38 & 4.15 & 2.91 & 11.8 & 10.1 & 19.4 & 57.2 & 36.0 \\
\hline \multicolumn{2}{|c|}{ Mean } & 5.49 & 0.93 & 3.65 & 4.16 & 0.53 & 3.61 & 7.14 & 4.17 & 5.00 & 3.54 & 4.28 & 3.50 & 4.28 & 3.03 & 12.0 & 10.3 & 19.8 & 58.4 & 37.0 \\
\hline \multirow{3}{*}{ 'Regent' } & CT & 5.53 & 1.00 & 3.61 & 4.13 & 0.58 & 3.47 & 6.99 & 4.06 & 4.72 & 3.51 & 4.26 & 3.59 & 4.07 & 3.06 & 11.8 & 9.78 & 19.0 & 56.7 & 36.5 \\
\hline & RT & 5.45 & 0.93 & 3.67 & 4.16 & 0.52 & 3.50 & 6.96 & 4.03 & 4.72 & 3.47 & 4.24 & 3.60 & 4.05 & 3.05 & 11.8 & 9.52 & 18.7 & 56.0 & 36.3 \\
\hline & NT & 5.60 & 0.98 & 3.49 & 4.05 & 0.60 & 3.35 & 6.94 & 4.01 & 4.68 & 3.49 & 4.20 & 3.56 & 4.02 & 3.02 & 12.0 & 9.64 & 19.0 & 56.6 & 36.1 \\
\hline \multicolumn{2}{|l|}{ Mean } & 5.53 & 0.97 & 3.59 & 4.11 & 0.57 & 3.44 & 6.96 & 4.04 & 4.71 & 3.49 & 4.23 & 3.58 & 4.05 & 3.04 & 11.9 & 9.65 & 18.9 & 56.4 & 36.3 \\
\hline \multicolumn{21}{|c|}{ LSD value } \\
\hline \multicolumn{2}{|c|}{ A } & ns & ns & ns & ns & ns & ns & $0.14^{*}$ & $0.12^{* *}$ & $0.22 * *$ & ns & ns & ns & $0.14^{* *}$ & ns & ns & 0.49 * & $0.41^{* *}$ & ns & ns \\
\hline \multicolumn{2}{|l|}{ B } & ns & ns & ns & ns & ns & ns & $\mathrm{ns}$ & $0.9^{*}$ & ns & ns & ns & ns & $0.11 *$ & ns & ns & ns & ns & ns & ns \\
\hline \multicolumn{2}{|l|}{$\mathrm{A} \times \mathrm{B}$} & ns & ns & ns & ns & ns & ns & ns & ns & ns & ns & ns & ns & $\mathrm{ns}$ & ns & $0.34 *$ & ns & $0.46^{*}$ & ns & $0.11 *$ \\
\hline
\end{tabular}

CT—conventional tillage; RT—reduced tillage; NT—no-tillage; ns—not significant; $\sum$ NEAA—non-essential amino acids; $\sum$ EAA—exogenous amino acids; ${ }^{*} p<0.05$ and ${ }^{* *} p<0.01$. 
The noted interaction resulted from the fact that the tillage system differentiated the values of these traits only in 'Dalbor'. The greatest variation was found with CT and NT: $0.24 \mathrm{~g} 16 \mathrm{~g}^{-1} \mathrm{~N}$, respectively. However, no significant difference was found between CT and RT. Moreover, in the yellow lupin and white lupin seeds, the calculated fractions of the exogenous amino acids (EAA) and non-essential amino acids (NEAA) varied depending on the variety and tillage system. In both species, the greatest value of these fractions was observed in the determinate 'Perkoz' and 'Boros' varieties. Simplifying the cultivation slightly increased their content.

The heatmap showed a significant variation in the amino acid content depending on the variety and cultivation system (Figure 2).

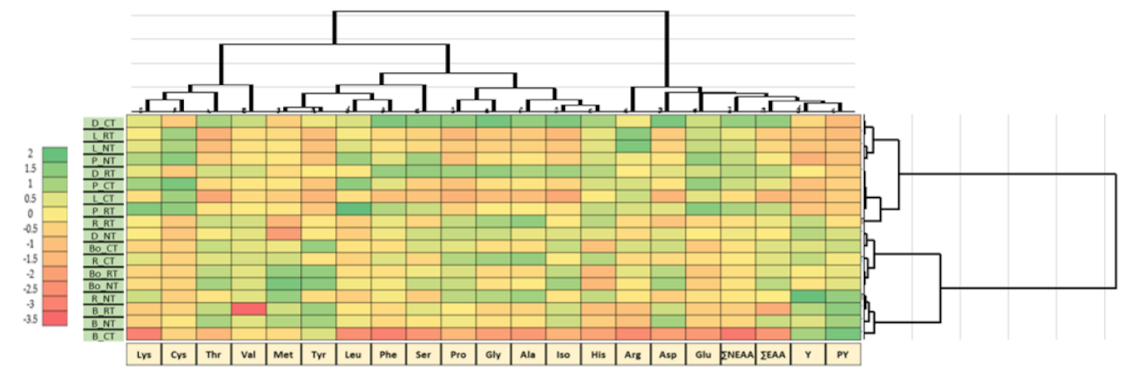

Figure 2. Relationship between amino acids, seed yield and protein yield. Normalized values were scaled (+2 > -3.5). D-'Dalbor'; L-'Lord'; P-'Perkoz'; R-'Regent'; Bo-'Boros'; B-'Butan'; $\mathrm{CT}$-conventional tillage; RT-reduced tillage; NT-no-tillage; $\sum$ NEAA—non-essential amino acids; $\sum$ EAA—exogenous amino acids; $Y$ —seed yield; PY—protein yield.

A lower concentration of most of the observed amino acids was recorded in the white lupin and yellow lupin seeds, and mainly in the indeterminate 'Butan' and 'Lord' varieties. Under CT cultivation, the lowest values of lysine, threonine, leucine, phenylalanine, serine, proline, glycine, alanine, isoleucine, histidine, arganine, aspartic acid and glutamic acid were observed in the indeterminate 'Butan' variety, and the lowest values of threonine, tyrosine, proline, glycine alanine, isoleucine and aspartic acid were observed in the 'Lord' variety. Similarly, the lowest level of exogenous amino acids in these varieties was recorded under the CT system. In addition, our study has shown that the variety with the greatest concentration of threonine, phenylalanine, serine, proline, glycine, alanine, isoleucine and aspartic acid was the indeterminate 'Dalbor' narrow-leaved lupin variety under both CT and RT systems. The grouping of varieties indicates, however, that among the studied species, high seed and protein yields are possible with the determinate 'Regent' narrowleaved lupin variety under NT systems and with the determinate 'Boros' white lupin variety regardless of the tillage system. The indeterminate 'Butan' under the CT system was found to have the lowest total NEAA and EAA values of the six lupin varieties across all three trials, with the 'Dalbor' found to be the greatest.

\section{Discussion}

\subsection{Organic Components, Ash and Macroelements}

The production of food for an ever-increasing human population and the protection of natural resources from pollution are the most important challenges currently facing the agricultural sector [27]. Lupins, such as white lupin, yellow lupin and narrow-leaved lupin, provide an excellent source of plant protein $[19,28,29]$. The protein content can be related to the species, variety, growing conditions and soil type [14]. The conducted research showed a diversified reaction of species, but also varieties and their chemical composition to the tillage system. In our study, the greatest protein content was observed in the yellow lupin seeds, and the lowest in narrow-leaved lupin. Similar results for the protein content were reported by Porres et al. [30] and Bartkiene et al. [9]. Between the compared species, the 
greatest differentiation for variety was found in yellow lupin, where the greatest protein content was found in the indeterminate 'Lord'.

The N-free extract content differs between lupin species and contains, in addition to starch and pectin, more water-soluble non-starch polysaccharides and oligosaccharides [28]. According to Saez et al. [31] and Struti et al. [32], the NFE content decreases after the dehulling of the lupin seeds, which permits its use for monogastric animal nutrition.

Our study shows that the content of A and NFE for all tested lupins did not vary between the variety. Furthermore, the tillage system also did not modify these features. A significant differentiation was shown in the case of the CL content in the determinate yellow lupin and white lupin seeds, and also the CF content in yellow lupin seeds. Similar ranges in the content of this nutrient in lupin seeds have been reported in the literature $[3,19,28]$. The mineral composition of legume seeds changes significantly depending on the genotype and habitat conditions [33,34], and also as a result of agrotechnical factors [15]. According to Grela et al. [3], phosphorus and potassium are well represented in narrow-leaved lupin and yellow lupin, whereas calcium is found in greater quantities in white lupin, and the high content in magnesium is characteristic for yellow lupin seeds.

The analysis of the macroelement content in our study indicates varietal differentiation. In narrow-leaved lupin, the greatest content of potassium was found in the seeds of the determinate 'Regent', whereas the greatest content of magnesium in yellow lupin was found in the seeds of the indeterminate 'Lord', and also for white lupin phosphorus content in the indeterminate variety. Similarly, Bartkiene et al. [9] observed a relationship between the macroelement content in lupin seeds and the variety.

The main goal of tillage soil is to create optimal conditions for plant growth, development and yielding. In our research, the tillage system caused differences in the contents of $\mathrm{CP}, \mathrm{CF}$ and potassium in the seeds of lupin. On combination with NT, in narrow-leaved lupin, the greatest $\mathrm{CP}$ content for both varieties and a lower $\mathrm{CP}$ content in the determinate 'Boros' were determined. In yellow lupine, a decrease in CF on reduced tillage for both studied varieties was observed. In white lupin, a lower potassium content in the determinate 'Boros' was determined.

Woźniak and Rachon [16], in their study on the response of reduced tillage in yellow lupin, observed that the tillage system had little effect on the contents of protein, phosphorus, magnesium and calcium in the seeds; however, the ash content of the seeds increased and the potassium content decreased in the NT system compared to the CT and RT systems. According to Wasilewko and Buraczewska [35], the chemical composition of seeds depends primarily on the species and less on the cultivar and year of harvest. Furthermore, good knowledge of the seeds of each lupin species or variety is essential for choosing the best lupin as a protein source, increasing the production of farm animals.

\subsection{Amino Acids}

The results of our study indicate that the variety and tillage system have less impact on the amino acid content in white lupin compared to the other lupin species in this study. A significant difference in variety was observed in white lupin only in the case of the arginine content. In the case of the narrow-leaved lupin, greater levels of leucine, phenylalanine, serine, isoleucine, aspartic acid and glutamic acid were observed in the indeterminate 'Dalbor', whereas greater levels of lysine, threonine, valine, leucine, phenylalanine, glycine, alanine, isoleucine, aspartic acid and glutamic acid were observed in the determinate yellow lupin 'Perkoz'. Similarly, Kotlarz et al. [36] observed differences in the chemical composition of narrow-leaved lupin, including the amino acid composition, due to the variety and sowing date. According to Tomczak et al. [37] narrow-leaved lupin seeds are especially rich in leucine, threonine and lysine, with 'Bojar' and 'Oskar' the richest among the 18 varieties examined in their study.

The present study demonstrated that the tillage system only slightly differentiated the content of amino acids. In the present study, the tillage system modified the content of phenylalanine and isoleucine only in the narrow-leaved lupin seeds. In both cases, a 
reduction in the number of agrotechnical treatments contributed to a decrease in the value of these amino acids.

\section{Conclusions}

Among the three lupin species, the yellow lupin exhibited the greatest protein content. The variety did not have a significant effect on the protein content. The highest protein content was only found in the NT system for narrow-leaved lupin, whereas these differences were not significant in yellow lupin and white lupin. The remaining organic components and ash content showed no differentiation under the influence of the examined factors. The evaluation of the amino acid composition of the protein in the lupin seeds showed that the differences depended to the greatest extent on the variation within the species. The conducted research shows that the varietal differentiation in terms of the amino acid content was particularly evident in narrow-leaved lupin and yellow lupin, and, to a much lesser extent, in white lupin. Greater amino acid contents were noted in the indeterminate and determinate forms for narrow-leaved lupin and yellow lupin, respectively. The tillage system did not modify the amino acid composition of yellow lupin and white lupin proteins. In narrow-leaved lupin, the tillage system only influenced the content of phenylalanine and isoleucine; the reduction in cultivation treatments contributed to a decrease in the content of these amino acids. The above results indicate that decreased tillage does not have a significant impact on the amino acid composition of the proteins of the three most commonly cultivated species of lupin, regardless of the variety. This would indicate their potential for use in practice, without negative consequences for the quality of the produced seeds.

Funding: This research was funded by The National Center for Research and Development under the CORNET initiative (CORNE T/2/15/2013). ProLegu: Innovative protein products from legume seeds, grown under conditions sustainable agriculture for the feeding of poultry.

Institutional Review Board Statement: Not applicable.

Informed Consent Statement: Not applicable.

Acknowledgments: Publication was co-financed within the framework of the Polish Ministry of Science and Higher Education's program: "Regional Initiative Excellence" in the years 2019-2022 (No. 005/RID/2018/19).

Conflicts of Interest: The author declares no conflict of interest.

\section{References}

1. Abraham, E.M.; Ganopoulos, I.; Madesis, P.; Mavromatis, A.; Mylona, P.; Nianiou-Obeidat, I.; Parissi, Z.; Polidoros, A.; Tani, E.; Vlachostergios, D. The use of lupin as a source of protein in animal feeding: Genomic tools and breeding approaches. Int. J. Mol. Sci. 2019, 20, 851. [CrossRef] [PubMed]

2. Smýkal, P.; Vernoud, V.; Blair, M.W.; Soukup, A.; Thompson, R.D. The role of the testa during development and in establishment of dormancy of the legume seed. Front. Plant. Sci. 2014, 5, 351. [PubMed]

3. Grela, E.R.; Kiczorowska, B.; Samolińska, W.; Matras, J.; Kiczorowski, P.; Rybiński, W.; Hanczakowska, E. Chemical composition of leguminous seeds: Part I-Content of basic nutrients, amino acids, phytochemical compounds, and antioxidant activity. Eur. Food. Res. Technol. 2017, 243, 1385-1395. [CrossRef]

4. Lucas, M.M.; Stoddard, F.L.; Annicchiarico, P.; Frias, J.; Martinez-Villaluenga, C.; Sussmann, D. The future of lupin as a protein crop in Europe. Front. Plant. Sci. 2015, 6, 705. [CrossRef] [PubMed]

5. Erbas, M. The effects of different debittering methods on the production of lupin bean snack from bitter Lupinus albus L. seeds. J. Food Qual. 2010, 33, 742-757. [CrossRef]

6. Kocira, A.; Staniak, M.; Tomaszewska, M.; Kornas, R.; Cymerman, J.; Panasiewicz, K.; Lipińska, H. Legume Cover Crops as One of the Elements of Strategic Weed Management and Soil Quality Improvement. A Review. Agriculture 2020, 10, 394. [CrossRef]

7. Panasiewicz, K.; Faligowska, A.; Szymańska, G.; Szukała, J.; Ratajczak, K.; Sulewska, H. The Effect of Various Tillage Systems on Productivity of Narrow-Leaved Lupin-Winter Wheat-Winter Triticale-Winter Barley Rotation. Agronomy 2020, 10, 304. [CrossRef]

8. Szpunar-Krok, E.; Kuźniar, P.; Pawlak, R.; Migut, D. The Effect of Foliar Fertilization on the Resistance of Pea (Pisum sativum L.) Seeds to Mechanical Damage. Agronomy 2021, 11, 189. [CrossRef] 
9. Bartkiene, E.; Bartkevics, V.; Starkute, V.; Krungleviciute, V.; Cizeikiene, D.; Zadeike, D.; Juodeikiene, G.; Maknickiene, Z. Chemical composition and nutritional value of seeds of Lupinus luteus L., L. angustifolius L. and new hybrid lines of L. angustifolius L. Zemdirb.-Agric. 2016, 103, 107-114. [CrossRef]

10. Peoples, M.B.; Brockwell, J.; Herridge, D.F.; Rochester, I.J.; Alves, J.R.; Urgulaga, S.; Boddey, R.M.; Dakora, F.D.; Battarai, S.; Maskey, S.L.; et al. The contribution of nitrogen-fixing crop legumes to the productivity of agricultural systems. Symbiosis 2009, 48, 1-17. [CrossRef]

11. Gorissen, S.H.M.; Crombag, J.J.R.; Senden, J.M.G.; Huub Waterval, W.A.; Bierau, J.; Verdijk, L.B. Protein content and amino acid composition of commercially available plant-based protein isolates. Amino Acids 2018, 50, 1685-1695. [CrossRef] [PubMed]

12. Nalborczyk, E. Biologiczne uwarunkowania produktywności roślin straczkowych [Biological conditions of legumes productivity]. Fragm. Agron. 1993, 4, 147-150. (In Polish)

13. Beyer, H.; Schmalenberg, A.K.; Jansen, G.; Jürgens, H.U.; Uptmoor, R.; Broer, I.; Huckauf, J.; Michel, V.; Zenk, A.; Ordon, F. Evaluation of variability, heritability and environmental stability of seed quality and yield parameters of L. angustifolius. Field Crops Res. 2015, 174, 40-47. [CrossRef]

14. Martínez-Villaluenga, C.; Frías, J.; Vidal-Valverde, C. Functional lupin seeds (Lupinus albus L. and Lupinus luteus L.) after extraction of $\alpha$-galactosides. Food Chem. 2006, 98, 291-299. [CrossRef]

15. Woźniak, A.; Soroka, M.; Stępniowska, A.; Makarski, B. Chemical composition of pea (Pisum sativum L.) seeds depending on tillage systems. J. Elem. 2014, 19, 1143-1152.

16. Woźniak, A.; Rachoń, L. Yellow lupine (Lupinus luteus L.) response to reduced tillage. Arch. Agron. Soil Sci. 2021. [CrossRef]

17. Sabo, M.; Jug, D.; Jug, I. Effect of reduced tillage on quality traits of soybean [Glycine max (L.) Merr.]. Acta Agronomica Hungarica. 2007, 55, 83-88. [CrossRef]

18. Górynowicz, B.; Święcicki, W.; Osiecka, A.; Kaczmarek, Z. Terminal inflorescence (ti) and restricted branching (rb) genes in lupins (L. albus L., L. angustifolius L., L. luteus L.) and field bean (Vicia faba L.) breeding in Poland. J. Agric. Sci. Technol. B 2014, 4, 712-721.

19. Yilmaz, S..; Mehmet, A.; Mustafa, E. Comparison of chemical composition in Lupin (Lupinus spp.) species. Revista de Chimie 2015, $66,324-327$.

20. Boschin, G.; D'Agostina, A.; Annicchiarico, P.; Arnoldi, A. Effect of genotype and environment on fatty acid composition of Lupinus albus L. seed. Food Chem. 2008, 108, 600-606. [CrossRef]

21. Saastamoinen, M.; Eurola, M.; Hietaniemi, V. The chemical quality of some legumes, peas, fava beans, blue and white lupins and soybeans cultivated in Finland. J. Agric. Sci. Technol. 2013, 3, 92-100.

22. Mierlita, D.; Simeanu, D.; Pop, I.M.; Criste, F.; Pop, C.; Simeanu, C.; Lup, F. Chemical Composition and Nutritional Evaluation of the Lupine Seeds (Lupinus albus L.) from Low-Alkaloid Varieties. Rev. Chim. 2018, 69, 453-458. [CrossRef]

23. IUSS Working Group WRB. World Reference Base for Soil Resources. International Soil Classification System for Naming Soils and Creating Legends for Soil Maps; Update 2015; World Soil Resources Report; FAO: Rome, Italy, 2015.

24. Walter, H. Strefy Roślinności a Klimat [Vegetation Zones and Climate]; PWRiL: Warsaw, Poland, 1976; pp. 26-31. (In Polish)

25. AOAC. Official Methods of Analysis of AOAC International, 18th ed.Horwitz, W., Latimer, G.W., Jr., Eds.; Revision 4; AOAC International: Gaithersburg, MD, USA, 2011.

26. SAS Institute. SAS/STAT User's Guide, 7th ed.; Carolina Inst.: Cary, NC, USA, 1999.

27. Bhardwaj, H.L.; Hamama, A.A.; Santen, E. White lupin performance and nutritional value as affected by planting date and row spacing. Agron. J. 2004, 96, 580-583. [CrossRef]

28. Sujak, A.; Kotlarz, A.; Strobel, W. Compositional and nutritional evaluation of several lupin seeds. Food Chem. 2006, 98, 711-719. [CrossRef]

29. Annicchiarico, P.; Harzic, N.; Carroni, A.M. Adaptation, diversity, and exploitation of global white lupin (Lupinus albus L.) landrace genetic resources. Field Crops Res. 2010, 119, 114-124. [CrossRef]

30. Porres, J.M.; Aranda, P.; López-Jurado, M.; Urbano, G. Nitrogen fractions and mineral content in different lupin species (Lupinus albus, Lupinus angustifolius, and Lupinus luteus). Changes induced by the r-galactoside extraction process. J. Agric. Food Chem. 2007, 55, 7445-7452. [CrossRef]

31. Saez, P.; Borquez, A.; Dantagnan, P.; Hernández, A. Effects of dehulling, steam-cooking and microwave-irradiation on digestive value of white lupin (Lupinus albus) seed meal for rainbow trout (Oncorhynchus mykiss) and Atlantic salmon (Salmo salar). Arch. Anim. Nutr. 2015, 69, 143-157. [CrossRef]

32. Struti, D.I.; Mierlita, D.; Simeanu, D.; Pop, I.M.; Socol, C.T.; Papuc, T.; Macri, A.M. The effect of dehulling lupine seeds (Lupinus albus L.) from low-alkaloid varieties on the chemical composition and fatty acids content. Rev. Chim. 2020, 71, 59-70. [CrossRef]

33. Wang, N.; Hatcher, D.W.; Warkentin, T.D.; Toews, R. Effect on cultivar and environment on physicochemical and cooking characteristic of field pea (Pisum sativum). Food Chem. 2010, 118, 109-115. [CrossRef]

34. Amarakoon, D.; Thavarajah, D.; Mcphee, K.; Thavarajah, P. Iron-, zinc-, and magnesium-rich field peas (Pisum sativum L.) with naturally low phytic acid: A potential food-based solution to global micronutrient malnutrition. J. Food Compos Anal. 2012, 27, 8-13. [CrossRef]

35. Wasilewko, J.; Buraczewska, L. Chemical composition including content of amino acids, minerals and alkaloids in seeds of three lupin species cultivated in Poland. J. Anim. Feed. Sci. 1999, 8, 1-12. [CrossRef] 
36. Kotlarz, A.; Podleśny, J.; Strobel, W. Zawartość wybranych aminokwasów egzogennych w białku nasion łubinu wąskolistnego w zależności od typu odmiany i terminu siewu. [Amino-acid composition of proteins in narrow-leaf lupine in relations to variety type and sowing date]. Acta Agrophysica 2009, 14, 115-123. (In Polish)

37. Tomczak, A.; Zielinska-Dawidziak, M.; Piasecka-Kwiatkowska, D.; Lampart-Szczapa, E. Blue lupine seeds protein content and amino acids composition. Plant Soil Environ. 2018, 64, 147-155. 